\title{
The effect of heat treatment and particle size of bran on mineral absorption in rats
}

\author{
BY ANDREA CAPREZ AND SUSAN J. FAIRWEATHER-TAIT \\ Agricultural Research Council, Food Research Institute, Colney Lane, \\ Norwich, Norfolk NR4 7UA
}

(Received 1 February 1982 - Accepted 14 June 1982)

\begin{abstract}
1. The effect of heat treatment of bran on true zinc absorption was measured using an isotope-dilution technique. A bran-based breakfast cereal (heated to $204^{\circ}$ for 40 min during manufacture) was incorporated into a semi-synthetic diet at a level of $180 \mathrm{~g} / \mathrm{kg}$. A parallel diet was formulated containing an identical weight of untreated bran from the same source plus other ingredients used to make the cereal.

2. Young male Wistar rats (mean weight $80 \mathrm{~g}$ ) were injected intramuscularly with ${ }^{65} \mathrm{Zn}$ to label body $\mathrm{Zn}$. They were given the heat-treated-and untreated-bran diets for $9 \mathrm{~d}$. During the last $6 \mathrm{~d}$ of this period $\mathrm{Zn}$ intakes and faecal and urinary $\mathrm{Zn}$ were measured in order to calculate apparent $\mathrm{Zn}$ retention. True $\mathrm{Zn}$ retention was measured by taking into account losses of $\mathrm{Zn}$ of endogenous origin (labelled with ${ }^{85} \mathrm{Zn}$ ), by measuring faecal and urinary ${ }^{\circ 5} \mathrm{Zn}$ and taking the mean specific radioactivity of $\mathrm{Zn}$ in kidneys and upper smali intestine to represent specific radioactivity of endogenous origin.

3. Heat treatment of bran removed approximately one-third of the phytate, but this was not enough to improve $\mathrm{Zn}$ absorption from the diet. True $\mathrm{Zn}$ retention measured by isotope dilution was significantly higher $(P<0.02)$ than apparent $\mathrm{Zn}$ retention measured by the conventional balance technique.

4. The hypothesis that a reduction in particle size of bran would improve mineral availability was tested by feeding coarse and milled bran $(100 \mathrm{~g} / \mathrm{kg}$ diet $)$ in a semi-synthetic diet to rats and measuring true $\mathrm{Fe}$ and apparent $\mathrm{Zn}$ absorptions. The importance of phytate was also investigated by feedin " a diet containing dephytinized bran.

5. Male Wistar rats (mean weight $172 \mathrm{~g}$ ) were given diets containing coarse, milled or dephytinized bran for $9 \mathrm{~d}$. $\mathrm{Fe}$ and $\mathrm{Zn}$ intakes were measured and faeces and urine collected for $\mathrm{Fe}$ and $\mathrm{Zn}$ analysis.

6. The mean ( $\pm \mathrm{SE}$ ) particle size of the bran was reduced on milling from $3.5( \pm 1.8)$ to $0.2-0.5 \mathrm{~mm}$. There were no differences in the fraction of Fe retained between the three groups. Particle size had a small effect on $\mathrm{Zn}$ retention which was marginally higher in rats on the milled-bran diet $(0.126( \pm 0.023))$ than in those on the coarse-bran diet $(0.087( \pm 0.012))$. Total removal of phytate had a greater effect and apparent $\mathrm{Zn}$ retention from the dephytinized-bran diet was significantly higher $(0.182( \pm 0.027), P<0.01)$.
\end{abstract}

Some foods that are rich sources of dietary fibre appear to reduce the bioavailability of minerals to man (McCance \& Widdowson 1942; Bjorn-Rasmussen 1974). However, it is unclear whether the effects of cereal fibre on the availability of iron and zinc are primarily due to the fibre itself (as suggested by Reinhold et al. 1975; Simpson et al. 1981) or to the phytate (present mainly in the aleurone layer of cereal grains) as suggested by Davies \& Nightingale (1975). Previous work in this laboratory (Fairweather-Tait, 1982) has indicated that the inhibitory effect of bran on Fe absorption is due to phytate rather than fibre since an increase in dietary fibre in bread with no change in phytate showed no reduction in $\mathrm{Fe}$ absorption in rats.

Phytate (myo-inositol hexaphosphate) is broken down by heat and by the action of phytase, an enzyme which occurs naturally in plants and also in the intestinal mucosae of man and rats (Bitar \& Reinhold, 1972). Most cereal products, such as breakfast cereals, breads, crispbreads and biscuits, are heat treated and this may influence the form (Cheryan, 1980 ) and level of phytate and thus reduce mineral-binding in the processed product. Since Davies \& Reid (1979) suggested that phytate-Zn interactions in foods may be an important factor influencing $\mathrm{Zn}$ status, we decided to see if heat treatment of a bran-based cereal product containing bran and small additions of sugar, salt and malt improved the availability of $\mathrm{Zn}$ by comparing $\mathrm{Zn}$ absorption in rats from the cereal before and after processing. 
Table 1. Heat-treatment experiment. Composition of bran diets $(\mathrm{g} / \mathrm{kg})$

\begin{tabular}{lccc}
\hline \hline Form of bran... & Untreated* & Heat-treated* & Milled $\dagger$ \\
\hline Albumen & 200 & 200 & 200 \\
Maize oil & 80 & 80 & 80 \\
Mineral mix $\downarrow$ & 40 & 40 & 40 \\
Vitamin mix & 20 & 20 & 20 \\
Starch & 240 & 280 & 280 \\
Sucrose & 272 & 200 & 280 \\
Milled bran & & 180 & 100 \\
Heat-treated bran cereal & 140 & & \\
Untreated bran & 4 & \\
Salt & 4 & \\
Dried malt & & \\
\hline
\end{tabular}

* Supplied by Kellogg Company of Great Britain Ltd, Stretford, Manchester.

† Supplied by Booker Health Foods Ltd, Byfleet, Weybridge, Surrey.

$\ddagger$ Included (g/kg diet): $\mathrm{CaHPO}_{4}, 13 \cdot 0 ; \mathrm{CaCO}_{3}, 8 \cdot 2 ; \mathrm{KCl}, 7 \cdot 03 ; \mathrm{Na}_{2} \mathrm{HPO}_{4}, 7 \cdot 4 ; \mathrm{MgSO}_{4} \cdot \mathrm{H} 2 \mathrm{O}, 4 \cdot 0 ; \mathrm{MnSO}_{4} \cdot \mathrm{H}_{2} \mathrm{O}$ $0 \cdot 18 ; \mathrm{ZnCO}_{3}, 0 \cdot 10 ; \mathrm{FeSO}_{4} .7 \mathrm{H}_{2} \mathrm{O}, 0 \cdot 144 ; \mathrm{CuSO}_{4}, 0 \cdot 015 ; \mathrm{KIO}_{3}, 0 \cdot 001$.

1| Included $(\mathrm{mg} / \mathrm{kg}$ diet): nicotinic acid, 60; cyanocobalamin in mannitol, 50; calcium D-pantothenate, 40; thiamin hydrochloride, 10; riboflavin, 10; pyridoxine, 10; pteroylmonoglutamic acid, 5 ; D-biotin, 1; menadione, 1; Rovimix E-25 (Roche), 300; Rovimix A-500 (Roche), 25; Rovimix A-500/D3 (Roche), 15; choline bitartrate, 1800 .

Bran is widely used as a dietetic food to reduce intestinal transit time and its palatability appears to be inversely related to particle size. Manufacturers, therefore, reduce particle size when bran is used as an additive in processed foods, in order to improve consumer acceptability. If there is a physico-chemical binding of minerals to fibre in the intestine (as suggested by Reinhold et al. 1975) changes in particle size and hence surface area will affect the absorption of minerals. Furthermore, the extent of phytate hydrolysis may depend on the amount of exposure of the aleurone layer to the intestinal mucosa which is a function of surface area of bran particles and time to pass through the intestine. We decided to test this hypothesis by looking for an increase in $\mathrm{Fe}$ and $\mathrm{Zn}$ absorptions with a reduction in bran particle size. At the same time we looked at the effect of dephytinizing the bran in order to obtain more information about the relative importance of fibre and phytate in reducing mineral availability.

\section{MATERIALS AND METHODS}

$\mathrm{Zn}$ absorption was measured by a radioisotope-dilution technique in the heat treatment (HT) experiment, and $\mathrm{Fe}$ and $\mathrm{Zn}$ absorption by chemical balance in the particle size (PS) experiment.

\section{$H T$ experiment}

A quantity of bran used in the manufacture of a breakfast cereal, and the formulated breakfast cereal were provided by Kellogg Company of Great Britain Ltd (Stretford, Manchester). In making the cereal the bran had been heated to $204^{\circ}$ for $40 \mathrm{~min}$ and milled before mixing with malt solution, sugar and salt and then cooling.

Both the cereal and the untreated bran were ground in a rotary knife mill with hardened-steel cutting knives. Malt, sugar and salt were added to the untreated bran in the same proportions as those used to formulate the cereal. The diet compositions are shown in Table 1.

A third diet was formulated using bran from a different source, supplied by Booker Health Foods Ltd (Byfleet, Weybridge, Surrey) and used in the PS experiment, which was also ground in the knife mill. This diet contained less bran to make the final phytate level in 


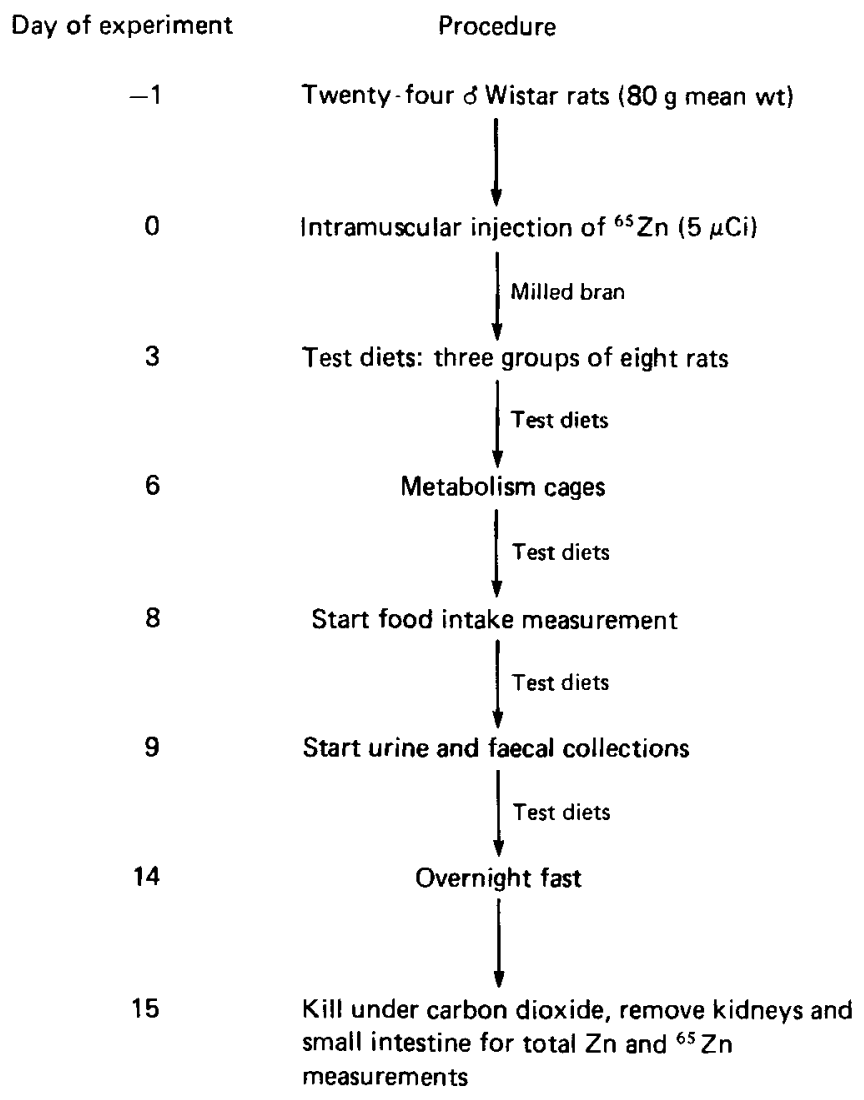

Fig. 1. Experimental procedure for heat-treatment experiment (radioisotope-dilution technique; for details, see below.

the diet similar to that in the heat-treated-bran diet. The untreated bran contained more phytate and therefore it was necessary to include a third group to see if any differences in $\mathrm{Zn}$ absorption between untreated- and heat-treated-bran diets could be attributed to differences in phytate levels of the diets. Diets were formulated (as near as possible) to contain the same proportion of dietary fibre and the bran in each diet milled to a similar particle size distribution.

\section{HT experiment}

Twenty-four male Wistar albino rats (mean weight $80 \mathrm{~g}$ ) were individually caged in plastic and stainless-steel cages with grid bottoms and given the milled bran diet ad lib. An outline of the experimental procedure is shown in Fig. 1. The animals were injected intramuscularly in the thigh muscle of the left hind-leg with approximately $0.1 \mathrm{ml}$ saline $(9 \mathrm{~g}$ sodium chloride/l) containing $50 \mu \mathrm{Ci}{ }^{65} \mathrm{Zn}$ (zinc chloride $0.1 \mathrm{~m}$-hydrochloric acid, carrier-free; Amersham International, Bucks.) $/ \mathrm{ml}$. The exact amount of ${ }^{65} \mathrm{Zn}$ injected was calculated from the difference in syringe weight before and after injection. The animals continued on the milled-bran diet for $3 \mathrm{~d}$ and were then randomly divided into three groups of eight. Group 1 was given a diet containing $140 \mathrm{~g}$ untreated bran $/ \mathrm{kg}$, Group 2 a diet containing $180 \mathrm{~g}$ heat-treated bran $/ \mathrm{kg}$ and Group 3 continued on the milled-bran diet containing $100 \mathrm{~g}$ bran $/ \mathrm{kg}$. After $3 \mathrm{~d}$ they were transferred to stainless-steel metabolism cages with plastic funnels for separate urine and faecal collections. Food intake measurements were started 
after $2 \mathrm{~d}$ and $1 \mathrm{~d}$ later faecal and urinary collections were begun and continued for a period of $6 \mathrm{~d}$. The animals were fasted for $24 \mathrm{~h}$ before killing under carbon dioxide, when the kidneys and a $150 \mathrm{~mm}$ segment (distal from the pylorus) of the small intestine were removed. Faeces, urine, kidneys and intestine were analysed for total $\mathrm{Zn}$ by atomic absorption spectrophotometry and for ${ }^{65} \mathrm{Zn}$ activity by gamma counting.

The true absorption of dietary $\mathrm{Zn}$ was calculated by the isotope-dilution technique of Weigand \& Kirchgessner (1976) as described by Evans et al. (1979). The amount of $\mathrm{Zn}$ absorbed $(A)$ was computed from the formula:

$$
A=\frac{i-f+(f . s f) / s m}{i}
$$

where $i$ is the $\mathrm{Zn}$ intake $(\mu \mathrm{g} / \mathrm{d}), f$ is the total faecal zinc excretion $(\mu \mathrm{g} / \mathrm{d}), s f$ is the specific radioactivity of $\mathrm{Zn}$ in the faeces and $s m$ is the specific radioactivity of $\mathrm{Zn}$ of endogenous origin. The average value of the specific activities of the intestine and kidney were taken as $s m$.

\section{PS experiment}

A quantity of coarse bran (Prewett's natural bran) was provided and a portion dephytinized by adding approximately $15 \mathrm{mg}$ phytase (Sigma Chemical Co. Poole, Dorset) to $100 \mathrm{~g}$ bran in $110.1 \mathrm{M}$-citrate buffer, $\mathrm{pH} \mathrm{5.2}$. The mixture was stirred for $3 \mathrm{~h}$ at $55^{\circ}$, the bran washed five times with distilled water, freeze-dried and milled. The phytate content was determined by the modified method of Holt (Davies \& Reid 1979). A further quantity of coarse bran was milled in a rotary knife mill (as used in the HT experiment) and the phytate contents of milled and coarse bran determined. The particle size distribution of the milled bran was determined by passing it through a series of graduated sieves.

Twenty-four male Wistar albino rats (mean weight $140 \mathrm{~g}$ ) were individually caged in stainless-steel metabolism cages with plastic funnels for separate urine and faecal collections. The rats were given a semi-synthetic diet similar to the milled-bran diet in the HT experiment containing $100 \mathrm{~g}$ dephytinized bran $/ \mathrm{kg}$ instead of milled bran for $3 \mathrm{~d}$. They were then weighed and randomly allocated to three groups of eight. Group 1 was given a similar diet containing $100 \mathrm{~g}$ coarse bran $/ \mathrm{kg}$, Group 2 a diet containing $100 \mathrm{~g}$ milled bran $/ \mathrm{kg}$ and Group 3 a diet containing $100 \mathrm{~g}$ dephytinized bran $/ \mathrm{kg}$.

Faeces and urine were quantitatively collected for $9 \mathrm{~d}$, and food intakes accurately measured. The animals were allowed distilled water and food ad lib. They were then weighed and killed under $\mathrm{CO}_{2}$. The $\mathrm{Fe}$ and $\mathrm{Zn}$ contents of faeces, urine and all three diets were measured by atomic absorption spectrophotometry.

\section{Analytical methods}

Atomic absorption spectrophotometry. Approximately $4 \mathrm{~g}$ samples of diets were accurately weighed in duplicate into silica crucibles. Faeces from the PS experiment were dried and ground and $1 \mathrm{~g}$ duplicates weighed into silica crucibles. Faeces from each rat in the HT experiment were placed in individual large silica crucibles, dried at $50^{\circ}$ for $72 \mathrm{~h}$ and weighed. The kidneys and segments of small intestine were individually placed in small silica crucibles and dried at $70^{\circ}$ for $72 \mathrm{~h}$ and weighed. All samples were dry ashed in a muffle furnace at $480^{\circ}$ for $36 \mathrm{~h}$ or more and the ash taken up in warm concentrated $\mathrm{HCl}$, made up to an appropriate volume with distilled water and filtered. The urine samples were passed through a sintered-glass filter and made up to $60 \mathrm{ml}$. The solutions were analysed by flame spectroscopy using a Varian AA6 atomic absorption spectrophotometer.

Dietary fibre. This was analysed by a modification (M. A. White \& D. A. T. Southgate, unpublished results) of the Southgate (1969) method.

Gamma counting. The measurement of ${ }^{65} \mathrm{Zn}$ was carried out directly on faeces and urine 
Table 2. Heat-treatment experiment. Zinc contents and specific radioactivities of small intestine, kidneys, faeces and urine

(Mean values with their standard errors)

\begin{tabular}{|c|c|c|c|c|c|c|}
\hline \multirow[t]{2}{*}{ Form of bran. } & \multicolumn{2}{|c|}{ Untreated } & \multicolumn{2}{|c|}{ Heat-treated } & \multicolumn{2}{|c|}{ Milled } \\
\hline & Mean & $\mathrm{SE}$ & Mean & $\mathrm{SE}$ & Mean & $\mathrm{SE}$ \\
\hline \multicolumn{7}{|l|}{ Intestine } \\
\hline$\mu \mathrm{g} / \mathrm{g}$ dry wt & $26 \cdot 9$ & $0 \cdot 9$ & $26 \cdot 3$ & 0.7 & $26 \cdot 5$ & 0.7 \\
\hline $\mathrm{nCi} / \mu \mathrm{g}$ & $0 \cdot 36$ & 0.01 & $0 \cdot 36$ & 0.01 & 0.41 & 0.01 \\
\hline \multicolumn{7}{|l|}{ Kidneys } \\
\hline$\mu \mathrm{g} / \mathrm{g}$ dry wt & $41 \cdot 4$ & 1.4 & $43 \cdot 7$ & $1 \cdot 0$ & $43 \cdot 3$ & $1 \cdot 1$ \\
\hline $\mathrm{nCi} / \mu \mathrm{g}$ & $0 \cdot 40$ & $0 \cdot 01$ & 0.40 & 0.01 & 0.44 & 0.01 \\
\hline$\mu \mathrm{g} / \mathrm{d}$ & 728 & 15 & 754 & 29 & 658 & 23 \\
\hline $\mathrm{nCi} / \mu \mathrm{g}$ & 0.057 & 0 & 0.059 & 0 & 0.064 & 0 \\
\hline \multicolumn{7}{|l|}{ Urine } \\
\hline$\mu \mathrm{g} / \mathrm{d}$ & 20 & 2 & 21 & 3 & 24 & 3 \\
\hline $\mathrm{nCi} / \mu \mathrm{g}$ & $0 \cdot 21$ & 0.02 & $0 \cdot 28$ & 0.02 & $0 \cdot 22$ & 0.03 \\
\hline
\end{tabular}

and on known volumes of solutions prepared for atomic absorption spectrophotometry in a Phillips Automatic Gamma Counter with a $75 \times 75 \mathrm{~mm} \mathrm{NaI}$ crystal, centre 550 , width 100 , gauge 15 . Standards of ${ }^{65} \mathrm{Zn}$ were prepared and the counting efficiencies obtained were $5.7 \%$ for $10 \mathrm{ml} \mathrm{samples}$ and $7 \cdot 4 \%$ for $5 \mathrm{ml}$ samples.

Statistical analyses. One-way analysis of variance was performed on all set of results. Where this showed a treatment effect, unpaired $t$ tests were performed comparing the different groups with each other (Snedecor \& Cochran 1967).

\section{RESULTS \\ $H T$ experiment}

During the period of urinary and faecal collections there were no differences in food intake or weight gain between the three groups of rats.

The $\mathrm{Zn}$ contents of the diets were similar: untreated-bran diet $67 \cdot 3 \mu \mathrm{g} / \mathrm{g}$, heat-treated-bran diet $69.7 \mu \mathrm{g} / \mathrm{g}$ and milled-bran diet $60.5 \mu \mathrm{g} / \mathrm{g}$. Dietary fibre contents were also similar: 69.6 $\mathrm{g} / \mathrm{kg}, 62.7 \mathrm{~g} / \mathrm{kg}$ and $59.0 \mathrm{~g} / \mathrm{kg}$ respectively. The phytate level of the untreated-bran diet $(16.5 \mathrm{~g} / \mathrm{kg})$ was higher than the heat-treated-bran diet $(4.3 \mathrm{~g} / \mathrm{kg})$ and the milled-bran diet $(4.5 \mathrm{~g} / \mathrm{kg})$.

The $\mathrm{Zn}$ contents and specific radioactivities of small intestine, kidneys, faeces and urine are given in Table 2. Each animal received a slightly different dose of ${ }^{65} \mathrm{Zn}$ and therefore the level of radioactivity (counts/min) obtained was adjusted accordingly so that results could be directly compared. Urinary losses of $\mathrm{Zn}$ and specific radioactivity of the urine were so small as to be negligible.

Table 3 shows the apparent and true absorptions and true retention of $\mathrm{Zn}$ by rats on the three diets. True absorption in the untreated-bran group was $0.409( \pm 0.023)$, in the heat-treated-bran group $0.426( \pm 0.01)$ and in the milled-bran group $0.434( \pm 0.022)$. There were no significant differences in true $\mathrm{Zn}$ absorption or retention between the three groups. As predicted, apparent absorption was significantly lower than true absorption $(P<0 \cdot 02)$. 
Table 3. Heat-treatment experiment. Apparent and true absorption and retention of zinc (Mean values with their standard errors)

\begin{tabular}{|c|c|c|c|c|c|c|}
\hline \multirow[t]{2}{*}{ Form of bran... } & \multicolumn{2}{|c|}{ Untreated } & \multicolumn{2}{|c|}{ Heat-treated } & \multicolumn{2}{|c|}{ Milled } \\
\hline & Mean & SE & Mean & $\mathrm{SE}$ & Mean & SE \\
\hline $\begin{array}{l}\text { Apparent absorption } \\
(i-f) / i \\
\text { Apparent retention }\end{array}$ & $0 \cdot 306$ & 0.011 & 0.319 & 0.012 & 0.334 & 0.025 \\
\hline & 0.287 & 0.012 & $0 \cdot 30$ & 0.012 & 0.310 & 0.027 \\
\hline$\frac{i-f+(f . s f) / s m}{i}$ & 0.409 & 0.008 & 0.426 & 0.01 & 0.434 & 0.022 \\
\hline $\begin{array}{l}\text { True retention } \\
\frac{i-f+(f . s f) / s m-u+(u . s u) / s m}{i}\end{array}$ & 0.401 & 0.009 & 0.421 & 0.011 & 0.421 & 0.023 \\
\hline
\end{tabular}

$i, \mathrm{Zn}$ intake $(\mu \mathrm{g} / \mathrm{d}) ; f, \mathrm{Zn}$ faecal excretion $(\mu \mathrm{g} / \mathrm{d}) ; u, \mathrm{Zn}$ urine excretion $(\mu \mathrm{g} / \mathrm{d}) ; s f$, specific radioactivity of faecal $\mathrm{Zn} ; s m$, specific radioactivity of endogenous $\mathrm{Zn} ; s u$, specific radioactivity of urinary $\mathbf{Z n}$.

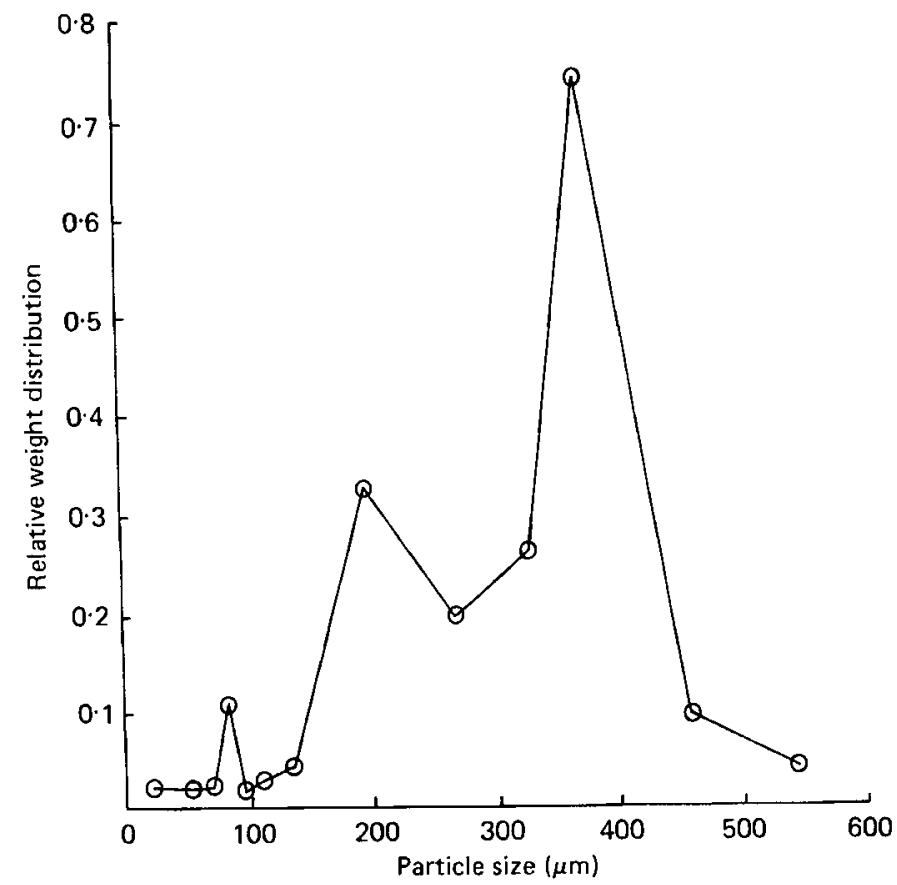

Fig. 2. Particle size distribution of milled bran used in particle size experiment (for details, see p. 470).

\section{PS experiment}

The mean particle size of the coarse bran was $3.5( \pm 1.8) \mathrm{mm}$. The distribution of particles in the milled bran is shown in Fig. 2; approximately $80 \%$ of the particles were between 0.2 and $0.5 \mathrm{~mm}$.

The $\mathrm{Fe}$ and $\mathrm{Zn}$ contents of the three bran diets were similar; coarse-bran diet $43.6 \mu \mathrm{g} / \mathrm{g}$, 
Table 4. Particle size experiment. Weights $(g)$ of rats; iron and zinc balance over 9-d period

(Mean values with their standard errors)

\begin{tabular}{|c|c|c|c|c|c|c|}
\hline \multirow[t]{2}{*}{ Form of bran... } & \multicolumn{2}{|c|}{ Coarse } & \multicolumn{2}{|c|}{ Milled } & \multicolumn{2}{|c|}{ Dephytinized } \\
\hline & Mean & SE & Mean & SE & Mean & SE \\
\hline Initial wt & 177 & 3 & 173 & 5 & 167 & 3 \\
\hline Final wt & 230 & 5 & 215 & 6 & 216 & 4 \\
\hline Wt gained & 53 & 3 & $43^{*}$ & 2 & 49 & 3 \\
\hline Fe intake (mg) & $6.83 \dagger$ & 0.13 & 5.90 & $0 \cdot 14$ & $5 \cdot 89$ & 0.25 \\
\hline $\mathrm{Fe}$ in urine $(\mu \mathrm{g})$ & 4 & 1 & 12 & 3 & 6 & \\
\hline $\mathrm{Fe}$ in faeces (mg) & $4 \cdot 76 t$ & 0.13 & $4 \cdot 35$ & $0 \cdot 18$ & 3.88 & 0.26 \\
\hline $\begin{array}{l}\text { Fe retained }(\mathrm{mg}) \\
\text { Fe retention }\end{array}$ & $2 \cdot 07 \|$ & 0.09 & 1.55 & 0.17 & $2 \cdot 01$ & $0 \cdot 14$ \\
\hline$\frac{\text { Intake }- \text { Excretion }}{\text { Intake }}$ & 0.303 & 0.013 & $0 \cdot 262$ & 0.03 & $0 \cdot 345$ & 0.03 \\
\hline Zn intake (mg) & 7.90 & $0 \cdot 15$ & $7 \cdot 33$ & $0 \cdot 18$ & $7 \cdot 23$ & $0 \cdot 30$ \\
\hline $\mathrm{Zn}$ in urine $(\mu \mathrm{g})$ & 167 & 12 & 154 & 11 & 158 & 16 \\
\hline $\mathrm{Zn}$ in faeces $(\mathrm{mg})$ & $7 \cdot 03 \S$ & $0 \cdot 11$ & $6 \cdot 28$ & 0.24 & 5.76 & $0 \cdot 31$ \\
\hline $\begin{array}{l}\mathrm{Zn} \text { retained }(\mathrm{mg}) \\
\mathrm{Zn} \text { retention }\end{array}$ & 0.709 & 0.09 & 0.91 & $0 \cdot 15$ & $1 \cdot 31$ & $0 \cdot 18$ \\
\hline$\frac{\text { Intake }- \text { Excretion }}{\text { Intake }}$ & $0.087^{* *}$ & 0.012 & $0 \cdot 126$ & 0.023 & $0 \cdot 182$ & 0.027 \\
\hline
\end{tabular}

* Mean value for milled-bran group was lower than that for coarse-bran group $(P<0.02)$.

$\dagger$ Mean value for coarse-bran group was higher than that for milled- and dephytinized-bran groups $(P<0 \cdot 01)$.

\$ Mean value for coarse-bran group was higher than that for dephytinized-bran group $(P<0 \cdot 02)$.

II Mean value for coarse-bran group was higher than that for milled-bran group $(P<0.05)$.

$\S$ Mean value for coarse-bran group was higher than that for milled- and dephytinized-bran groups $(P<0.02, P<0.01$ respectively).

T Mean value for coarse-bran group was lower than that for dephytinized-bran group $(P<0.02)$.

** Mean value for coarse-bran group was lower than that for dephytinized-bran group $(P<0.01)$.

$50.4 \mu \mathrm{g} / \mathrm{g}$, milled-bran diet $41.0 \mu \mathrm{g} / \mathrm{g}, 50.9 \mu \mathrm{g} / \mathrm{g}$ and dephytinized-bran diet $37.6 \mu \mathrm{g} / \mathrm{g}$, $46.1 \mu \mathrm{g} / \mathrm{g}$ respectively. The dietary fibre levels differed; the coarse-bran diet was lowest at $53.2 \mathrm{~g} / \mathrm{kg}$, the milled-bran diet was next at $61.9 \mathrm{~g} / \mathrm{kg}$ and the dephytinized-bran diet highest at $78.0 \mathrm{~g} / \mathrm{kg}$. The higher dietary fibre content of the milled-bran diet is probably a result of the milling procedure in effect concentrating the dietary fibre in the bran, as a small amount of residual starchy endosperm of lower fibre content was lost from the bran as it was milled. Significant amounts of starch were removed during dephytinization, hence the even higher level of dietary fibre. Phytate levels were the same in the coarse-and milled-bran diets at $4.5 \mathrm{~g} / \mathrm{kg}$. No phytate was detectable in the dephytinized-bran diet.

The mean weights of the rats are shown in Table 4 . The weight gain of the group given milled bran was significantly less $(P<0.02)$ than that of the group given coarse bran. Their food intakes were also lower. No other significant differences in weight gain were observed.

The results of the $\mathrm{Fe}$ and $\mathrm{Zn}$ balance are also shown in Table 4. Losses of Fe (and $\mathrm{Zn}$ ) in the urine were very small. There was a significantly higher intake of $\mathrm{Fe}$ in the coarse-bran group $(P<0.01)$ than in the other two groups. Faecal Fe excretion was also significantly higher $(P<0.02)$ in the coarse-bran group than in the dephytinized-bran group but, as a result of the higher $F e$ intake, when $F e$ retention was calculated, the coarse-bran group retained significantly more Fe than the milled-bran group $(P<0.05)$. However, when $\mathrm{Fe}$ 
retention was expressed as a proportion of $\mathrm{Fe}$ intake there were no differences between the three groups.

$\mathrm{Zn}$ intakes were similar in all three groups but faecal $\mathrm{Zn}$ excretion was significantly higher in the coarse-bran group than the milled- $(P<0.02)$ or dephytinized-bran group $(P<0.01)$. $\mathrm{Zn}$ retention was significantly lower in the coarse-bran group than the dephytinized-bran group $(P<0.02)$ and when expressed relative to intake, $\mathrm{Zn}$ retention was significantly lower $(P<0.01)$ in the coarse-bran group than the dephytinized-bran group. There was no significant difference in retention between the coarse- and milled-bran groups, retentions being 0.087 in the coarse-bran group, 0.126 in the milled-bran group and 0.182 in the dephytinized-bran group.

\section{DISCUSSION}

Heat treatment of bran affects its chemical and physical form. Wet heat processing first solubilizes and then destroys pectic substances (Anderson \& Clydesdale, 1980) and has a significant effect on metal binding in vitro (Camire \& Clydesdale, 1981). In man, transit time is reduced and stool size increased to a greater extent with raw than with cooked bran (Wyman et al. 1976).

Our study showed no effect of heat treatment on $\mathrm{Zn}$ availability to young rats. However, it is clear from the results that the true absorption of $\mathrm{Zn}$, as measured by the radioisotopedilution technique, is much higher than apparent absorption measured by the conventional balance technique. This is because pancreatic secretions contain high concentrations of $\mathrm{Zn}$ (Matseshe et al. 1980) and the intestine is therefore exposed to two sources of $\mathrm{Zn}$, endogenous (mainly from pancreatic secretions into the duodenum) and exogenous (from the diet). Thus part of the faecal $\mathrm{Zn}$ is not unabsorbed dietary $\mathrm{Zn}$ but $\mathrm{Zn}$ of endogenous origin. Indeed, it has been postulated that part of the control of $\mathrm{Zn}$ homeostasis is effected by secretion of $\mathrm{Zn}$ into the intestine rather than by regulation of $\mathrm{Zn}$ absorption (Evans et al. 1979).

True $\mathrm{Zn}$ absorption was 0.43 in the milled-bran group whereas apparent absorption was $0 \cdot 33$. During the experimental period the rats grew from an initial mean weight of $133 \mathrm{~g}$ to a final mean weight of $150 \mathrm{~g}$. The PS experiment showed an apparent $\mathrm{Zn}$ retention from the same milled-bran diet of 0.126 which is less than half that in the HT experiment. This is because the rats were older, with an initial mean weight of $172 \mathrm{~g}$ and final mean weight of $220 \mathrm{~g}$. The results illustrate the dramatic effect of age (i.e. growth requrements) in the rat on $\mathrm{Zn}$ absorption, and point to the importance of physiological factors rather than dietary factors in influencing $\mathrm{Zn}$ absorption from a diet of relatively high $\mathrm{Zn}$ availability. Without the values for true $\mathrm{Zn}$ absorption (which give a measure of endogenous $\mathrm{Zn}$ losses) we do not know to what extent $\mathrm{Zn}$ homoeostasis was being controlled by $\mathrm{Zn}$ secretion into the intestine.

The components of bran are changed during its passage through the alimentary tract. Dintzis et al. (1979) found that wheat bran was stripped of adhering endosperm and aleurone layer, and that bran particles isolated from human faeces had lost approximately $15 \%$ cellulose and $60 \%$ hemicellulose. It is probable that the efficiency of digestion (including hydrolysis of phytate present in the aleurone layer) is related to particle size. Smaller particles may be degraded more thoroughly by bacteria in the intestine and the resultant increase in available substrate will enhance bacterial growth. Assuming that the weight of increased bacterial numbers is less than the weight of bran degraded by bacteria, the final faecal weight should be less. It has been shown that faecal weights in human subjects were significantly less with fine bran than with coarse bran (Brodribb \& Groves, 1978) and in the present study we found a small difference in faecal dry weights. Rats on the milled-bran diet had slightly lower faecal weights than those on the coarse-bran diet $(P<0 \cdot 1)$. The particle size of the bran appeared to have a marginal influence on $\mathrm{Zn}$ but not Fe availability in rats. Mean faecal $\mathrm{Zn}$ excretion was greater in rats given a diet containing coarse bran 
than those given milled bran. When results were expressed relative to intake, the value for rats given the coarse-bran diet was 0.087 and for those given the milled-bran diet was $0 \cdot 126$. These differences were not statistically significant but the results must be interpreted with caution as there was a very wide scatter within each group, and the numbers of animals used were only eight per group.

$\mathrm{Zn}$ retention from the diet containing dephytinized bran $(0 \cdot 182)$ was significantly higher than from the coarse-bran diet $(P<0.01)$, but removal of phytate appeared to have no influence on Fe retention. The major form of $\mathrm{Fe}$ in bran is monoferric phytate (Morris \& Ellis, 1976) and this has been shown to be well absorbed by rats, thus indicating that the phytate is broken down during digestion, releasing the Fe for absorption. However, monoferric phytate accounts for less than $5 \%$ of the total phytate content of bran (Simpson et al. 1981) and the different effect of phytate on $\mathrm{Fe}$ and $\mathrm{Zn}$ availability may be related to the different strengths with which the divalent cations are bound to the phytate in the intestine.

In conclusion, it would appear that heat treatment of bran had no effect on $\mathrm{Zn}$ availability from the diet in the rat. The heat treatment used to manufacture the breakfast cereal reduced the phytate level from $36 \cdot 1$ to $23.9 \mathrm{~g} / \mathrm{kg}$, but this was not sufficient to improve $\mathrm{Zn}$ availability. Reduction in particle size of bran slightly improved $\mathrm{Zn}$ (but not $\mathrm{Fe}$ ) retention but due to the wide scatter and small numbers of animals used the results were not conclusive. When the bran was dephytinized, $\mathrm{Zn}$ availability was significantly increased although there was no effect on Fe.

The authors would like to thank the Kellogg Company of Great Britain for supplying the formulated breakfast cereal and samples of bran from which it was made, and Booker Health Foods for supplying Prewett's Natural Bran. They would also like to thank Ms V. Simmonds for assistance with the animals and Dr D. A. T. Southgate for advice in the preparation of this paper.

\section{REFERENCES}

Anderson, N. E. \& Clydesdale, F. M. (1980). J. Fd Sci. 45, 1533

Bitar, K. \& Reinhold, J. G. (1972). Biochim. biophys. Acta 268, 442.

Bjorn-Rasmussen, E. (1974). Nutr. Metab. 16, 101.

Brodribb, A. J. M. \& Groves, C. (1978). Gut 19, 60.

Camire, A. L. \& Clydesdale, F. M. (1981). J. Fd Sci. 46, 548.

Cheryan, M. (1980). CRC Crit. Rev. Fd Sci. Nutr. 13, 297.

Davies, N. T. \& Nightingale, R. (1975). Br. J. Nutr. 34, 243.

Davies, N. T. \& Reid, H. (1979). Br. J. Nutr. 41, 579.

Dintzis, F. R., Legg, L. M., Deatherage, W. L., Baker, F. L., Inglett, G. E., Jacob, R. A., Reck, S. J., Muñoz, J. M., Klevay, L. M., Sandstead, H. H. \& Shuey, W. C. (1979). Cereal Chem. 56, 123.

Evans, G. W., Johnson, E. C. \& Johnson, P. E. (1979). J. Nutr. 109, 1258.

Fairweather-Tait, S. J. (1982). Br. J. Nutr. 47, 243.

McCance, R. A. \& Widdowson, E. M. (1942). J. Physiol., Lond. 101, 44.

MacMasters, M. M., Hinton, J. J. C. \& Bradbury, D. (1971). In Wheat Chemistry and Technology, p. 51. [Y. Pomeranz, editor]. St. Paul, Minnesota: American Association of Cereal Chemists.

Matseshe, J. W., Phillips, S. F., Malagelada, J-R. \& McCall, J. T. (1980). Am. J. clin. Nutr. 33, 1946.

Morris, E. R. \& Ellis, R. (1976). J. Nutr. 106, 753.

Ranhotra, G. S., Lee, C. \& Gelroth, J. A. (1979). Nutr. Rep. Int. 19, 851.

Reinhold, J. G., Ismail-Beigi, F. \& Faradji, B. (1975). Nutr. Rep. Int. 12, 75.

Sandstead, H. H., Muñoz, J. M., Jacob, R. A., Klevay, L. M., Reck, S. J., Logan, G. M., Dintzis, F. R., Inglett, G. E. \& Shuey, W. C. (1978). Am. J. clin. Nutr. 31, 1180.

Simpson, K. M., Morris, E. R. \& Cook, J. D. (1981). Am. J. clin. Nutr. 34, 1469.

Southgate, D. A. T. (1969). J. Sci. Fd Agric. 20, 331.

Snedecor, G. W. \& Cochran, W. G. (1967). Statistical Methods, 6th ed. Ames, Iowa: Iowa State University Press.

Weigand, E. \& Kirchgessner, M. (1976). Nutr. Metab. 20, 314.

Weigand, E. \& Kirchgessner, M. (1980). J. Nutr. 110, 469.

Wyman, J. B., Heaton, K. W., Manning, A. P. \& Wicks, A. C. B. (1976). Am. J. clin. Nutr. $29,1474$. 